\title{
The Cultural Tradition of "Falia" in Preserving Forest by Munanese Ethnic
}

\author{
La Taena ${ }^{1}$, Zalili Sailan ${ }^{2}$, La Nalefo ${ }^{3}$, Ali Basri ${ }^{1}$, Ader Laepe ${ }^{2}$, Samsul $^{4}$, Siti Helmina ${ }^{5}$, La Miliha ${ }^{2} \&$ Wa Kuasa ${ }^{6}$ \\ ${ }^{1}$ Department of Social Science Education, Faculty of Teacher Training and Education, Halu Oleo University, \\ Kendari, Indonesia \\ ${ }^{2}$ Department of Arts and Language Education, Faculty of Teacher Training and Education, Halu Oleo University, \\ Kendari, Indonesia \\ ${ }^{3}$ Department of Agri-Business, Faculty of Agriculture, Halu Oleo University, Kendari, Indonesia \\ ${ }^{4}$ Department of English Literature, Faculty of Cultural Science, Halu Oleo University, Kendari, Indonesia \\ ${ }^{5}$ Department of Oral Tradition, Faculty of Cultural Science, Halu Oleo University, Kendari, Indonesia \\ ${ }^{6}$ Department of Antropology, Faculty of Cultural Science, Halu Oleo University, Anduonohu, Kendari, Indonesia \\ Correspondence: Wa Kuasa, Department of Antropology, Faculty of Cultural Science, Halu Oleo University, \\ Anduonohu, Kendari 93232 Sulawesi Tenggara, Indonesia. Tel: 62-8-1140-6599. E-mail: \\ wakuasa.Baka@uho.ac.id
}

Received: September 11, 2015 Accepted: October 8, 2016 Online Published: September 27, 2016

doi:10.5539/jsd.v9n5p200 URL: http://dx.doi.org/10.5539/jsd.v9n5p200

\begin{abstract}
This study aimed to describe and analyze the meaning of the tradition of "falia" in preserving forests in Muna Island in Southeast Sulawesi, Indonesia, by employing a qualitative descriptive method. Key sources of informants were figures of culture, society and youth. Data collection techniques included observation, focus group discussion and documentation. Data analysis consisted of reduction, data presentation and conclusion.Results showed that in preserving forests Munanese people uphold the tradition of "falia" which they consider very important in controlling people's behavior their moral life, as well as in guiding humans behavior towards their natural environment. It is suggested that humans maintain and preserve forest each other, forest should be sacred and utilized as needed. Humans are prohibited from cutting down or slashing large trees. Haphazardly cutting down large trees may result in supernatural punishment in the form of disease inflicted by spirits inhabiting the tree. It is also forbidden to cut down trees near river. The tradition of "falia" is maintained through traditional institutions, by setting up a studio for discussion sheld in every village adjacent to a forest.
\end{abstract}

Keywords: tradition of falia, forest conservation

\section{Introduction}

A number of research on the tradition of taboo, or "falia" in Munanese language, has been conducted around the world by, among others, Begossi, A. (2), Berkes, F.(3), Chaim, et al. (4), Colding, J. (5), Colding, J.F. (6), Costa-Pierce, B. (7), Daruna et al.(12), Dwyer, P.D. (13), Dennis Masaka et al. (8), Diamond, J. (9), Dodo Obediah, et al. (10), Doroighbo (11), Gadgil (15), Giddens, Anthony (16). Johan Kolding et al. (17), Johanes, R.E. et al. (18), Kaire (20), M.L Khan, et al. (21), Munamato Chemhuru, et al. (23), Ohmagari, Berkes (26), Okowonko Wo (27), Prasad, R. (29), Pretty, (30), Rabearivony et al. (12), Saka Olah Dunnijimoh, et al. (31), Tunner (36), and White (37).

In Indonesian contexts, it has been studied by Franky Samperante (32), Fukuyama, M. (14), Tamalene,M.N et al. (22), Nababan (24), Pieterz J.H. (28), Keraf S. A. (19), Sartini (33), Suyuti and Aris (34) in Muslimat and Waskit Hasim (34). In local settings, a tradition of taboo in Buton has been researched by Balawa (1) and Nalefo (25), and in Muna by Taena, et al. (35).

Local-specific traditional wisdom, such as falia or taboo, can be found in almost every country in the world. For instance, in Zambia a tradition of taboo serves as a social system that regulates and controls social behaviors (10). It also represents one's identity and will result in punishment if violated. In Africa, individual merit is measured based onthe extent to which one obey taboos. Taboo is also used as guidance for the upholding of social morality 
(8). In Stockholm, Sweden, taboo plays a role in directing human's behaviors in managing their natural environment and resources. The same case is present in Ahupua, Hawai, where forests are safely managed under the protection of taboo, as well as in Nigeria where some forests are regarded as sacred since they are believed to have the potentials for developing resources and maintaining ecosystem. In India, trees and forests are believed to be inhabited by spirits; thereby it is forbidden to utilize them, a violation of which may spark anger from the spirits (2). In the same country, it is believed that human, earth, and land are integrally connected to each other, so that the utilization of land must comply with cultural and ecological specifity of local society (29). Even more, in the state of Arunachal Prades India some tribes and ethnics have long protected their forests and sacred gardens as a way to observe their cultural taboos and totem beliefs. In some African countries, there exist some customary rules which prohibit people from cutting down trees near waterlines, and a sanction applies if this is violated (12), (27), (11), (20).In Madagaskar, Africa,combining cultural values and taboo norms in forest conservation programhas provided the society with an incentive for preserving forest and other natural resources (31). Zimbabwe is widely known for its zone of environmental taboo, which proves to be instrumental not only in the preservation of natural environment but also in the wise utilization of natural resources. Sacred places are common in this country; where people are not allowed to cut down trees in the forest.They appreciate harmonious life, collectively expressing their strong opposition to any forms of destruction on flora and fauna, strictly applying moral sanction to those who are found to cut down trees (23).

In Cameroon, customary institutions are very important in the management of natural resources, such as wild animals and communal protected forests. A worldview of environmental ethics is adopted in this country (37). Furthermore, what the society does in relation to its ecology is dependent on how it perceives itself and its relationship with other entities around it. The society respects animals, forests, and rivers; it never causes stress and cuts down trees, nor destroys, kills, and consumes them (36).

Ecosystem society considers nature and living things, including forest and rivers, as its relative, and its heirs worship and calm them down through customary ceremonies, which have traditionally been practiced as the habits of ecosystem societal groups (15). Indigenous people's expectation of the nature is limited by taboos, which dictate the extent to which the nature must be left undistracted (forest must be kept untouched). This type of traditional knowledge has been accumulated from generation to generation, although it often fails to reach future generation (26).

Traditional knowledge and local wisdom concerning with forest preservation are also found in Indonesia, for example in Tobelo Dalam, a region in Halmahera, where a local wisdom related to forest management continues to be applied by the people there, to the extent that the wisdom seems to be able to last forever (22). In Borneo, a local wisdom is still held by Dayak traditional communities, leading to traditional forest management, friendly people, and sustainable energy sources. In Papua, the indigenous people of Malind, Muyu Mandobo, Mippi and Auyu in Mereuke, live in the upper reaches of the river by making a cottage in the woods on a regular basis. They are highly dependent on forest ecosystems, believing that their lands contain sacred values of their ancestral spirits. The indigenous communities protect and preserve forests in a sustainable manner, believing that forests are sacred places (32). A similar local wisdom is present in East Nusa Tenggara, where indigenous Sasak people manage forests on a regular basis, a typical behavior in managing natural resources that have been passed from generation to generation (24). In Padang, a local wisdom is still maintained by the local people in their efforts to maintain forest, as are in Maluku Islands in Irian Jaya, where a local wisdom plays a role in regulating an integrated system of environmental ecosystems (28). In Buton, a study on local wisdom has been conducted, for example, by a research entitled "Pemali Dalam Aspek Didaktik Dalam Pemali Seometik Tradisi Lisan Masyarakat Ciacia", which maintains that it is very important to conduct an education in customarily polite behaviors, discipline, positive characters, love, and respect for oneself and natural environment (1). Similarly, a study on Munanese local wisdom entitled "Dimensi Pedagogik Dalam Makna Budaya "Falia" Pada Masyarakat Muna" reports that the tradition of "falia" contains a lot of cultural elements loaded with educational values, such as the need to appreciate the work and service of others, high work ethic, and prohibition against cutting down trees haphazardly (35). People in Buton take part in efforts to conserve forest in order to ensure the sustainability of agriculture practiced by farming communities living around the forest (25). The tradition of "falia" is a local wisdom adopted byMunanese ethnic. It concerns with an abstinence that must not be violated by a person or group and contains a lot of cultural values regarding the conservation of forest and environment. This tradition has long been embraced by the Munanese, passed down by generations. As stated by La Ode Sirad Imbo (aged 78 years), "falia" is a tradition that is based on a philosophy adopted by Munanese, i.e. dopomasimasighao, dopoangka angkatau, dopo-pia piara, which refers to mutual affection and nurture of each other, and to maintain this philosophy people must take care of each other and preserve forest (interview 
conducted at the informant's residence, August $23^{\text {rd }}, 2014$ ). The purpose of this study was to describe and analyze the meaning of "falia" tradition in relation to forest conservation.

\section{Research Method}

The study was conducted in Muna regency. Nowadays some people observe the tradition of "falia" in various walks of their life.Time needed to carry out this study was six months.

Informants were selected through purposive and snowballing techniques, in which one informant was determined based on the information provided by former informant, resulting in the selection of some traditional local figures and four ordinary people.

Data were collected through observation, in-depth interview, documents study, archive records, and focus group discussion.The techniques of data collection were as follows: observation technique was conducted on the condition of Munanese ethnic which expresses "falia". This was performed to some contexts in order to study the expressions of taboo, in terms of (1) to whom the expressions of taboo were addressed, (2) in what situation was the expressions of taboo were uttered, either formal (in processions of cultural events) or non-formal (relaxed situations), and (3) how were the expressions of taboo delivered: face to face or indirectly via aiding devices. The interview technique was conducted by visiting informants, from which data were collected, and asked them some questions that have been prepared before hand. Given the types of the questions, in-depth interviews were conducted. The recording technique was performed on a number of data to ensure that the data obtained were intact and comprehensive. This was done by using camera and other recording devices. The note-taking technique was used to take note of relevant data, both in the field and in the literature. This was conducted by using an instrument of data cards the researcher kept on carrying with him. The data were analyzed by employing a descriptive analytical method, and interpreted by following the phases below:

(1) Data reduction, which summarizes jots down, codifies, and transcribes oral into written forms. The expressions of "falia" are transcribed in the forms of texts, and then translated from Munanese language to Bahasa Indonesia, grouping them by characteristics.

(2) Data presentation, which presents data generated from data reduction phase in an organized and easily understandable way. The data where then presented in the forms of quoted interview with informants.

(3) The conclusion of the study was directed to address the research problems, i.e. describing and explaining the cultural tradition of "falia" concerning forest preservation.

\section{Discussion}

\subsection{The Meaning of "Falia" Tradition in the Preservation of Forest by the Ethnic of Muna}

"Falia" (prohibition) has long been embraced by the ethnic of Muna, passed down from generation to generation, as a way of life and identity (4). Taboo is considered part of one's identity. (8). Taboo plays an important role in all life zones,particularly in shaping human behaviors and encouraging people to become environmentally friendly since everyone has the responsibility for protecting the environment. Munanese people adopt a philosophy called dopo pia-piara, which is defined as mutual maintenance and preservation of forests. Rooted in this philosophy is the notion of "falia", which prohibits taking up, using, and managing forests in ways that are contrary to their life philosophy. In a broader sense, preservation offorestsis deemed equal to the maintenance of state, nation, and human themselves. Munanese people believe that nature and forest would be friendly if humans preserve them. "Falia" in the ethnic of Muna also imparts an ecological wisdom which dictates that to be put forward there needs to be appropriate arrangement based on an ancestral concept of the utilization of forest.

It was revealed by La Ode Sirat Imbo (aged 78), a descendant of the last King of Muna, who is also a cultural figure and a community leader, that prior to cutting down trees humans need to understand their identity, first reflecting, then honoring the creator since forests must be conserved and maintained (interview conducted at the informant's residence on June $23^{\text {rd }}, 2014$ ).

Based on this mindset, Munanese societies have adopted some customs and cultures containing the values of environmental preservation or conservation of forests which are embodied in the living and keeping together because forests can serve as an identity, which is its special characteristic. Furthermore, self-awareness needs to be raised when cutting trees by remembering its creator. It is held by Munanese peoplethat nature is not only an object to be exploited solely for worldly interests, as part of life and livelihood.The universe, the woods, and the water also serve as an identity, meaning that humans and forests are always together for fulfilling their needs, they need each other, people always recognize them and get know each other. Self-awareness means that forest and nature should not be exploited; that consciousness, sincerity, and honesty must be maintained in order to 
keep human from cutting down trees, which will cause destruction and deforestation; and that people should remember its creator, the Almighty God (34). Therefore, in the tradition of "falia", any arbitrary act, such as cutting down trees haphazardly, is subject to the torment of the Almighty.

Munanese understanding of trees is that, in addition to recognizing their creator, they must be sacred (7). Water and forests are protected by taboos. Some forests and water are sacred because they have the potential to promote ecosystem resilience. Forests and trees are sacred because they are considered as the source of human life, therefore they must be maintained and they should not be disturbed nor cut down haphazardly (27). If one mangrove tree is cut down, then it must be replaced by replanting ten mangroves trees. In this way, the ancestral people of Muna have created a way of controlling human behaviors in all life activities, includingthe preservation of environment called "falia". Since ancient time, Munanese people has suggested the need to preserve the environment, among others, through the tradition of "falia" (or the prohibition of cutting down trees haphazardly). An informant named La Ode Mboka-Mboka (78 year old), who is a public figure in Muna, stated that there is an agreed customary rule regarding the procedures for cutting down trees:

"Ane detugho sau bhalano beano dokatindae deki depakeane poluluwhich means that before cutting down a tree, the tree must firstly be cut by thrusting an axe into the tree trunk, then leaving it for a day or two. If, after the day elapsed, the axe is still there, then it indicates no spirits inhabit the tree and it is safe to cut down the tree" (interview conducted at the informant's residence on December $11^{\text {th }}, 2014$ ).

This indicates that since ancient times Munanese people have not cut down trees haphazardly because trees are sacred and preserved, and any forest-clearing activity has been bound by customary rules which have been convened together and should not be broken. Big trees are especially feared since they are believed to be most likely inhabited by spirits. Therefore, it is strictly forbidden to cut them down haphazardly.

La Sola, an informant aged 68 years old, said "ofalia dekati-katinda laano sau bhalahano, bheta nofohimogho tungguno sau bhahi domanansaki", which means that it is a "falia"(prohibited) for a human to slash or cut down trees because if the spirit inhabiting the tree feels disturbed then it can cast a disease to the human (interview conducted at the informant's residence on Augustus $5^{\text {th }}, 2013$ ).

Based on this view, forest conservation has been practiced by Munanesepeople since ancient times and today a tree or forest is still believedto be home to spirits, which can misbehave, disturb, or even harm humans. If tree and forest are destroyed, the spirits will disturb people living around it. For this reason, Munanese people are very cautious in cutting down trees. So deep is their belief in the existence of spirits inhabitingtrees that whenever theyare passing or being around a big tree,they often feel nuere wulu, orthe eerie atmosphere near the tree causes the hair on their arms or head to rise, which they term nosigari wuluno. If things get worse, people can experience a psychological disturbance, and under an extreme condition, a member of the relative or even the whole villagers may suffer from a disease break-out, a condition commonly called as nokantibae walelei.

It is this sort of supernatural belief that serves as a control so that all members of society in Muna do not haphazardly cut down trees nor encroachforest excessively.To the indigenous people in Papua, this is known as Malind, Muyu, Mandobo, Mippi Auyu, which meansthat people can only make cottagesin the woods on a regular basis; thatthey are highly dependent on forest ecosystems; and that their land contains sacred values because they are inhabited by spirits (32). Indigenous Papuans protect their forests, making them well-preserved since ancient times. They manage their forests in a sustainable manner, considering some forest as sacred. Based on what was found on the majority of Indian tribes in the area of Premachal Prodes, sacred forests and plantations are preserved based on the rules of local customs (21). In line with these findings, the informant La Ode Mboka-Mboka, a 78-year-oldcultural figure, states that if one wishes to cut down trees, then he must consider "ofalia" (prohibition) detughosaubhalahanokofolono peda obhake, ajampaka, tongkoea bhahi domanansakiane, meaning that it is strictly prohibited to cut down big gummy trees like banyan, jampaka, and tongkaea trees becase doing so can cause illness (interview on September $8^{\text {th }}, 2014$ ).

It is indicated bythislocal wisdom that Munanese people have long time ago been prohibited from cutting down gummy and big trees, since this sort of trees commonly grow in graveyard where spirits are believed to occupy. This implies that the spirits should be left to live undisturbed in gummy trees so that they do not cause undesirable things to people living in villages.

In case people want to cut down trees or clear a land, the local people are always required to begin with fesolo, a ritual to ask permission from supernatural beings existing nearby the land or trees. This ritual is led by a shaman believed to possess supernatural powers that enable him to communicate with spirits. This must be done because nature is believed to be occupied not onlyby human beings but also other creatures (supernatural beings) so that people must mind their actions and behaviors (34). 
The idea of ecological preservation embedded in "falia" as embraced by Munanese people reinforces a thesis that in all communities around the world, including in Indonesia, there exists local knowledgeof managing the surrounding environment. The indigenous people of Sasak in NTT possess a knowledge system and management of natural resources and ecology that has been inherited and developed for generations (24). Furthermore, all forms of knowledge, beliefs, customs, and ethics have been guiding human behaviors in living their life that requires ecological community. Similarly, in the area of Padang (West Sumatra) every effort to maintain the forest is a form of local wisdom, which have been be lived, practiced, taught, passed down from generation to generation, and shaped the patterns of human behaviorsand their interaction with nature, environment, and occult world (19).

Also found in some communities in Maluku islands and most parts of Irian Jaya is local wisdom "in which an integrated system of allocating and utilizing land and sea ecosystems is local-specific", complete with customary institutions to guarantee that the local system works effectively (28). As an example, some customary institutions in some parts of Maluku run a sustainable management of certain areas and biological varieties.Other example can be found in the adaptation of indigenous communities of Dayak tribe in Kalimantan,where its local wisdom has been instrumental in dealing with unfertilized lands (14).In India, for example, it is believed that human beings, seeds, and lands are integrally interconnected to each other. Therefore, it is forbidden to utilize a land beyond its main purpose or to use it not in accordance with the specific ecology and culture of local people. In some African communities exist some customary rules that prevent people from cutting trees near waterways (12), (27), (11), (20), (30). A system of memorial agriculture which was applied by core farmers (monor estate) in the middle age is also an example of ecological wisdom because landlords took advantages of the ways and culture of farming communities around their manors.

"Falia" as a cultural management of environment embraced by Munanese communities has confirmed other similar findings (28), (33), (29). It is an indication that there are varieties and similarities among local wisdoms in every region in Indonesia, their core teaching being the need to preserve and maintain environment as a source of human life. By way of example, in Tobelo Dalam, a region in Halmahera, a local wisdom pertinent to forest management has been applied to the extent that the wisdom seems to be able to survive forever (22). A similar case is found in Buton regency where a local wisdom concerning forest preservation proves instrumental in ensuring agricultural sustainability for the farming communities around the forests.(25).

That is how the wisdoms of traditional cultures organize, guide, and direct its supporting community, in order to create social order in the life of mankind in the universe in general. The wisdoms of traditional culture, and the tradition of "falia" in particular, contain universal humanity values. On this ground, it is necessary to make every effort to revitalize or utilize local wisdom in the society through the digging out, criticism, formulation, and careful planning so that the wisdoms embedded in the tradition of "falia" can function properly and optimally (16). Efforts to proportionally create the traditional values of a society is referred to as the process of post-traditionalisation, in which people embrace and uphold the traditional values, without having to be traditional.

In addition, it is necessary to take strategic steps to the reinforcement of the local wisdom through the followings. Firstly, strengthening both modern and traditional institutions of Munanese society, as a forum for participating in and coordinating the preservation and development of local wisdom. One concrete way is through the revitalization of traditional institutions as a means to develop the values of local wisdom. Secondly, developing human resources as the stakeholders, conservationists, and developer of local knowledge by providing access to and control of efforts to increase intellectual capacity. Thirdly, conducting educational, conservational, and promotional activities. Internally, it concerns with the effort to the inheritance or transformation of local wisdom from older generation to the younger generation through formal education and families, whereas externallyit is related to efforts to promote Munanese local wisdoms in various events and mass media, as well as throughinter-ethnic diplomacy and exchange of information. Fourthly, developing a regulation, for an umbrella of customary laws is needed to guard the positive development of local wisdom. Fifthly, pooling available resources, as it is realized that development naturally leads to the diversification and specialization, which in turn will cause the local knowledge to diversify. Therefore, it is important to make every effortto coordinate and integrate various resources associated with local wisdoms, including human resources, funding, network, and various areas of expertise in local, national, and global dimensions.

\section{Conclusion}

Based on the discussion above, it can be concluded that the tradition of "falia" embraced by Munanese people which has been inherited from generation to generation is still maintained; it is an indigenous knowledge that is 
spread through oral tradition, which specifies all activities that are prohibited in human life. In relation to forest conservation, it is philosophically called dopo pia-piara, meaning that human beings and natural environment need to take care of each other, so that it serves as a guidance for managing forests in human life, always caring to the environment. In preservation efforts, forest and trees should be well-maintained and kept together, as we should do in maintaining our country, nation, and ourselves. Munanese people adopt an ecological wisdom which dictates that it is necessary to have an arrangement according to the ancestral concept of "falia" dekati katinda laano sau balahano, bheta nofohimogho tungguno sau bahi domanansaki, which means that it is a "falia" (prohibition) to inflict an injury to or cut down big trees, for if the spirits inhabiting the trees are disrupted they can cast disease to humans. The significance of forest conservation has been practicedby Munanese people since ancient time, and today it is still believed that big tree or forest is home to spirits, which can disturb humans anytime. For this reason, humans must be very careful in encroaching and cutting down trees or forests, and to conserve forest, it is necessary to be established traditional institutions, such as a studio where discussion can be held and conducted in every village adjacent to what remains from the forests.

\section{References}

Balawa, L. O. (2009). Aspek Didaktik dalam "Pemali "Telaa semiotika sebuah tradisi Masyarakat Ciacia di Kabupaten Buton (In Indonesia).

Begossi, A. (2012). Resilience and neotraditional population: The caicaras of the Atlantic forest and cabaclos of the amazon (Brazil). 7. Indegenous African Resource Sacred Ecology Netpris, 480-Sacred Ecology- 2012(9780415517324).

Berkes, F. (1999). Sacred Ecology.Traditional ecological knowledge and resource management. Taylor and Francis, Philadelphia and London, UK.

Calding, J., \& Folke, C. (2001). Social Taboos:"Invisible" System of Local Resource Management And Biological Conservation. Ecological Applications, 11(2), 584-600.

Chaim, F., Gneezi, U., \& Hoffman, M. (2011). Taboos and Identity:Considering The Unthinkable. American Economic Journal: Microeconomics, 2(3), 139-164.

Chemhuru, M., \& Masaka, D. (2010). Taboos As Sources of Shona People's Enviromental Ethics. Departement of Philosophi and Relegious Studies, Great Zimbabwe Univerity. Journal of Sustainable Development in Africa, 12(7).

Colding, J. (1987). Analysis of hunting option by the use of general food taboos. Ecological Modelling, 110, 5-17. http://dx.doi.org/10.1016/S0304-3800(98)00038-6

Colding, J., \& Folke. (1997). The relation between threat-and species, their protection, and taboos. Conservation ecology, 1(1), 6. Retrieved from http://www.consecol.org/voll/iss1/art6

Costa-Pierce, B. A. (2012). Ecological Aquaculture. In Costa Piece, B. A. (Ed.), Ocean Farming And Sustanable Aquakulture Sceince And Tecnology. Encyclopedia Of Sustanabylity Science Technology (pp. 533-542). Springer Science, N.Y. http://dx.doi.org/10.1007/978-1-4419-0851-3_172

Diamond, J. (1993). New Guineans and their natural world. In S. R. Kellert, \& E. O. Wilson (Eds.), The biophilia hypothesis. Island Press, Washington, D.C., USA.

Doroigbo, C. I., Ibeawuchi, II., Aja, O. O., \& Ejiogu-Okereke, E. N. (2011). Indogenous Technologies for Adaptation and Mitigation of Climate Change in Sub-Sahara Africa. International Journal of Agriculture and Rural development, 14(2), 630-637.

Durruna, C. S., Chiaka, II., Ebenebe, O. E., Udedibie, A. B. I., Uchgbu, M. C., \& Durruna, O. N. (2011). Value of Bitter Leaf (Veminia Amigdalina) Meal as Freed Ingredient in the Dief of Finisher. International Journal of Agriculture and Rural development, 14(2), 722-726.

Dwyer, P. D. (1994). Modern conservation and indigenous peoples: in search of wisdom. Pacific Conservation Biology, 1, 91-97. http://dx.doi.org/10.1071/PC940091

Fukuyama, M. (1999). Organic Forming Via-aOVis Agriculture Rodale Press, USA.

Gadgil, M. (1987). Diversity: Cultural and Biological. Trends in Ecology and Evolution, 2, 369-7. http://dx.doi.org/10.1016/0169-5347(87)90138-8

Giddens, A. (2003). Masyarakat Post-Tradisional. Penerjemah: Ali Noer Zaman. Yogyakarta: IRCiSoD

Jimoh, S. O., Ikyaagba, E. T., Alarape, A. A., Obioha, E. E., \& Adeyemi, A. A. (2012). The Role of Traditional 
Laws and Taboos in Wildlife Conservation in the Oban Hill Sector of Cross River National Park (CRNP), Nigeria. J Hum Ecol, 39(3), 209-219.

Johannes, R. E. (Ed.). (1989). Traditional ecological knowledge: a collection of essays. International Conservation Union (JUCN), Gland, Switzerland.

Keraf, S. A. (2003). Etika Lingkungan, Pn Buku Kompas, Jakarta. (In Indonesian).

Khan, M. L., Khumbongmayum, A. D., \& Tripathi, R. S. (2008). The Sacred Groves And Their Significancein Conserving Biodiversity An Overview. International Journal Of Ecologyand Enviromental Sciences, 34(3), 277-291.

Koire, O. C., Eze, C. C., Lemchi, J. L., Orebiyi, J. S., Obasi, P. C., Ohajianya, D. O., \& Eza, U. E. (2011). An Overview of Benefits of Organic Agriculture as a Climate Change Adaptation and mitigation Strategy for Nigeria. International Journal of Agriculture and Rural development, 14(2), 638-645.

Masaka, D., \& Chemhuru, M. (2011). Dimensi Moral pada Beberapa Shona Tabu (Zviera). Journalof Sustainable Development in Africa, 13(3), 132-147.

Nababan. (2003). Pengelolaan Sumber Daya Alam Berbasis Masyarakat Adat. Tantangan dan Peluang.

Obediah, D., Everisto, N., \& Kasanda Sichalwa, M. (2014). Traditional Taboos and Konflict Resolution: An Exploration Of the Nexus. European Journal of Academic Essays, 1(3), 8-14.

Ohmagari, K., \& Berkes, F. (1997). Transmission of Indigenous Knowledge and Bush Skills Among the Western James Bay Cree Women of subarctic Canada. Human Ecology, 5(2), 197-222. http://dx.doi.org/10.1023/A:1021922105740

Okowonko Wo, M. O., \& Mbah, O. (2011). Resource Use Efficiency by Rural Poor Cassava Farmers in Imo Statel Implication for Poverty Allevation. Interrnational Journal of Agriculture and Rural Development, 14(2), 610-613.

Pietersz, J. H. (2009). Dari Aturan adat ke Etika (Kearifan Lokal) dan Peraturan Lingkungan Modern dalam hubungannya dengan Kelestarian Lanskap (Kajian Berdasarkan Pengalaman Kasus di Pulau Saparua, Propinsi Maluku). Ambon: Unpati Press. (In Indonesian)

Prasad, R. (2005). Organic Farming Vis-à-vis Medcine Agriculture. Curent Science, 89(2).

Pretty. (1990). Memorial Agriculture System Low Institution Development. IIED. London.

Samperante, F. (2011). Tanah Papua: Perjuangan yang Berlanjut untuk Tanah dan Penghidupan. Edisi Khusus. No. 89-90 Hal. 8 (In Indonesian).

Sartini. (2004). Menggali Kearifan Lokal Nusantara, Sebuah Kajian Filsafat. Jurnal Filsafat, Jilid 37. Yogyakarta: Universitas Gajah Mada (In Indonesian).

Suyuti, N., \& Aris. (2007). Bentuk Kearifan Lokal dam Menjaga Kelestarian Lingkungan Hidup pada Suku Bangsa Wuna di Kabupaten Muna, Dalam: Mengungkap Kearifan Lingkungan Sulawesi Tenggara. Penyunting: Muslimat dan Wakit Hasim. Makassar: Masagena Press (In Indonesian).

Taena, L., Basri, A., Ode, L., \& Laepe, A. (2013). Dimensi Pedagogik dalam Makna Budaya Tradisi Falia pada Masyarakat Muna. Jurnal Mudra Seni Budaya, 29(1), Hal. 91.

Tamalene, M. N., Al Muhdhar, M. H. I., Suarsini, E., \& Rochman, F. (2014). Praktik Kearifan Lokal dari Tobelo Dalam (Togutil) Komunitas Suku Dihutan Konservasi di Halmahera, Indonesia (In Indonesian). International Journal Of Plant Research, 4(4A), 1-7.

Tunner. (2002). Ecologycal Agriculture. Oxford Blackwel Science. U.S.A.

White, L. (2012). Upon Reading Lynn WhitesThe Historical Roots of Our Ecologic Crisis. Jr. Source: Science, New Series, 155(3767), 1203-1207. Retrieved August 5, 2009, from http://www.jstor.org/stable/1720120

\section{Copyrights}

Copyright for this article is retained by the author(s), with first publication rights granted to the journal.

This is an open-access article distributed under the terms and conditions of the Creative Commons Attribution license (http://creativecommons.org/licenses/by/4.0/). 